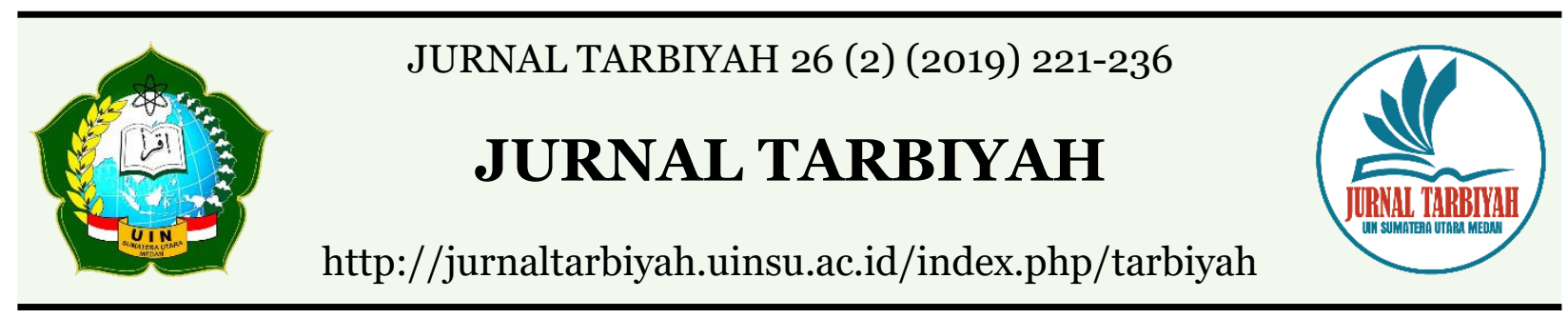

\title{
THE ROLE OF SCHOOL PRINCIPALS IN IMPROVING TEACHER PERFORMANCE IN MUHAMMADIYAH KARANGTURI ELEMENTARY SCHOOL YOGYAKARTA
}

\author{
Tulaihah Ning Safitri', Muhammad Rizqi Hidayat² \\ ${ }^{1}$ Nahdhatul Ulama University, Jakarta, Indonesia \\ 2 Yogyakarta State University, Yogyakarta, Indonesia \\ Email: ${ }^{1}$ lehatulaihah@gmail.com, 2 rizqihidayat1994@gmail.com
}

DOI : 10.30829/tar.v26i2.479

Accepted: August 18th, 2019. Approved: December 21th, 2019. Published: December 25th, 2019

\begin{abstract}
This study aims to analyze the role of school principals in improving the performance of elementary school teachers in Muhammadiyah Karangturi Yogyakarta, along with supporting and inhibiting factors in improving the performance of elementary school teachers in Muhammadiyah Karangturi Yogyakarta. This study uses qualitative research using descriptive-analytic methods. To get the data, researchers went directly in the field (field research). In analyzing data, researchers gradually use data reduction, data presentation, and data verification. Besides, in analyzing the performance of teacherresearchers using data indexing procedures. The results of this study indicate that the school principal in his role as the highest leader in this institution has a positive impact on improving the performance of elementary school teachers in Muhammadiyah Karangturi. This is evident that (a) The teacher is ready to implement the new curriculum. (b) The teacher uses learning strategies that are more creative and innovative. (c) The teacher can evaluate student learning by applicable curriculum requirements, namely in cognitive, affective, and psychomotor aspects. (d) The teacher teaches not only the material but also moral responsibility.
\end{abstract}

Keywords: Role of School Principals, Teacher Performance Improvement 
Tulaihah Ning Safitri, Muhammad Rizqi Hidayat / JURNAL TARBIYAH 26 (2) (2019) 221-236

\section{INTRODUCTION}

The quality of educationc will be successful if it is processed or processed with techniques and methods that are appropriate to the conditions and situations of students and use adequate facilities and infrastructure. To be able to do this it is necessary for Educators who have high ability and creativity and have high enthusiasm and work motivation so that they can produce good work productivity. In other words, teachers who have these elements are more likely to work better which means they have better work performance or performance.

Work performance or performance is the work of quality and quantity achieved by an employee in carrying out their duties by the responsibilities given to him (Mangkunegera, 2004: 67). Job performance is influenced by ability and motivation factors. The motivating factor that drives every employee is formed from the employee's attitude in dealing with work situations. This includes attitudes towards work related to the Principal's leadership. Teachers who have a positive attitude or agree with the situation of the school including the Principal's management, tend to be highly motivated so that they will work well and produce satisfying achievements or performance. On the other hand, teachers who do not agree with the school situation, including school principal management, tend to lack enthusiasm in working and their work is not optimal.

Considering educators as the spearhead that cannot be separated from weaknesses and strengths, the principal's role as a manager in an educational institution is responsible for fostering subordinates to achieve the expected goals following the vision and mission of the school that has been set, especially in improving the performance of educators. Because of this goal, improving the performance of educators in an educational institution is the main task of a school principal.

The leader is a decision-maker and also an example for its members, therefore a leader can at least set a good example for its members. As a decision-maker and policymaker, a leader must have one aspect that has a very important role in leading the organization concerned (Saroni, 2006: 15). The failure of a leader is leading his organization according to Sondang P. Siagian (2004: 146) can result in three negative things, namely:

1. Organizational members will exhibit behavior that is reflected in negative behavior, for example, frequent neglect, the excitement of work and low productivity, demands that are difficult to be accepted by common sense and other negative 
Tulaihah Ning Safitri, Muhammad Rizqi Hidayat / JURNAL TARBIYAH 26 (2) (2019) 221-236

actions. So it can be concluded that their behavior is detrimental to the organization as a whole.

2. The actions of members of the organization are aimed at satisfying the needs of personal interests. That is, they take actions that are detrimental to the organization but may personally benefit.

3. Members of the organization leave the organization, either gradually or suddenly, moving to another organization.

From this description, it can be understood that a person's leadership will be able to move his subordinates to do the best for his organization. Thus, the importance of the influence of the role of the Principal in an educational institution to improve the performance of the Teachers.

\section{REVIEW OF LITERATURE}

\section{Educational Management Concepts}

Etymologically the word "management" comes from the Latin language, which is "mano" which means hands and added affixes "agree" which means to do something so that it becomes manageable which means to do something many times using hands. Meanwhile, according to the terminology, the notion of management is an attempt to regulate the organization to achieve the goals set effectively, efficiently, and productively. (Imam Machali \& Ara Hidayat, 2016: 1-2). Meanwhile, according to Hersey (2008: 5) that "Management as the process of working with and through individuals and groups and other resources (such as equipment, capital, and technology) to achieve organizational goals".

Furthermore, etymological education according to Abu Ahmadi and Nur Uhbiyati (2007: 67) comes from the word "pedagogies" from the Greek, consisting of the word "pais" meaning child and "again" means to guide, so if interpreted, pedagogies means guidance given to a child. In the Roman language according to Abdul Kadir et al. (2012: 59) that education comes from the word "educate" which means removing something from within. Whereas in English education is termed the word "to educate" which means improving morale and intellectual training.

According to Law No. 20 of 2003 Education is a conscious and planned effort to create an atmosphere of learning and learning process so that students actively develop their potential to have spiritual strength, self-control, personality, intelligence, noble character, and the skills needed by themselves, society, nation, and country. 
Tulaihah Ning Safitri, Muhammad Rizqi Hidayat / JURNAL TARBIYAH 26 (2) (2019) 221-236

According to Bush and Coleman (2000: 4) states "Management of education is a study and practice that is linked or directed in the operations of educational organizations". Educational organizations need some form of activity regulation. The regulation of these activities leads to a systematic system. The systematic arrangement of activities will be used as a benchmark in the implementation of operational activities that are realized in education management. Suharsimi (2008: 4), states "Management of education is an activity or a series of activities in the form of a collaborative management business process of a group of people who are members of an educational organization, to achieve predetermined goals, to be effective and efficient".

Based on the above opinion it can be concluded that education management is a form of collaboration of a group of people, both the study and operational practices of the administration of education to realize educational goals effectively and efficiently. Educational management essentially has almost the same meaning as the school management. However, education management has a wider range than school management. Some of these meanings indicate that education management as a whole process of joint activities in the field of education by utilizing all available resources that are managed to achieve educational goals.

School Management essentially has almost the same meaning as education management, it's just that the scope is much smaller than education management. School management is limited to one school while education management covers all components of the education system. According to Saudagar, (2011: 141) school management is how the substance of education in a school can run orderly, smoothly and truly integrated into a system of cooperation to achieve goals effectively and efficiently. In conclusion, the school management is part of education management or the application of education management in school organizations as a component of the prevailing education system. Because school management is limited to one school, whereas education management covers all components of the education system.

In a course, management is needed collaboration, a group of people, and goals to be achieved. Of course in undergoing the process must be right on target and appropriate. To achieve these objectives management is needed in management where all forms of activities are grouped in components. The components of education management include: (a) student management; (b) personnel management; (c) curriculum management; (4) facility management; (5) financing management: (6) management of 
Tulaihah Ning Safitri, Muhammad Rizqi Hidayat / JURNAL TARBIYAH 26 (2) (2019) 221-236

educational institutions and finally; (7) public relations management (Suharsimi Arikunto, 2008: 4).

Meanwhile, according to Suharno (2008: 19), there are at least seven school components that must be managed properly in the framework of School-Based Management (SBM), namely: (a) curriculum and teaching; (b) education staff; (c) student affairs; (4) finance; (5) facilities and infrastructure; (6) management of school and community relations special service management and time management.

School management must be able to meet the eight standards set in Government Regulation No. 19 of 2005, namely: (a) content standards; (b) graduate competency standards; (c) process standards; (4) standards of educators and education personnel; (5) standard of facilities and infrastructure; (6) management standards; (7) assessment standards; (8) education financing standards. The eight standards above are the subject of study in analyzing the management of the Karangturi Muhammadiyah elementary school in Yogyakarta.

\section{School Leadership Concepts}

Furthermore, Principal Leadership is the key to the success of educational institutions. The principal comes from two words "head and school". The word head is defined as the chairman or leader in an organization or institution. While schools are an institution where they receive and give lessons (Ministry of National Education, 1988: 420,796).

Simply stated, Mulyasa (2004: 126) explains that the madrasa head is the driving force and determinant of madrasa policy, which will determine how goals in education can generally be realized. The Principal according to Wahjosumidjo (2007: 81) is a functional teacher of teachers who are given the task to lead a school where there is interaction between the teacher who gives lessons and students who receive lessons. Then understanding

The Principal according to Daryanto (2010: 80) explains that: The School Principal is the school personnel responsible for all school activities, has the authority and responsibility to carry out all educational activities in the school environment he leads on the basis of Pancasila which aims to: (1) Increase devotion to God Almighty. (2) Improve intelligence and skills. (3) Enhancing manners. (4) Strengthen personality. (5) Strengthening the spirit of nationalism and love for the motherland. 
Tulaihah Ning Safitri, Muhammad Rizqi Hidayat / JURNAL TARBIYAH 26 (2) (2019) 221-236

The Principal as a vital element for effectiveness in educational institutions determines the high or low quality of the institution, the Principal is likened to the commander of education who carries out the control function of various patterns of teaching and education activities in it. Therefore, the success of an institution depends on the extent to which the implementation of the mission is imposed on its shoulders, personality, and ability to get along with the elements in it.

Ara Hidayat and Imam Machali (2016: 83) formulated that fourteen categories show effective such as:

1. Planning and organizing (planning and organizing), including: (a) Determining long-term goals and strategies, (b) Allocating resources according to priorities, (c) Determine how to use personnel and resources resources to produce task efficiency, and (d) Determine how to improve coordination, productivity and effectiveness of organizational units.

2. Problem-solving, including (a) Identifying work-related problems, (b) Analyzing the problem at the right time but in a systematic way to identify causes and find solutions, and (c) Act decisively to implement solutions to solve important problems or crises.

3. Explaining roles and objectives (clarifying roles and objectives), including (a) Dividing tasks, (b) Giving direction on how to do the work, (c) Communicating a clear understanding of the responsibilities of the job, and the task objectives, deadlines, and expectations regarding performance.

4. Giving information (informing), including (a) Sharing relevant information about decisions, plans, and activities to people who need them to be able to do their work, (b) Providing written material and documents, and (c) Answering demand for technical information.

5. Monitoring (monitoring), including: (a) Gathering information on work activities and external conditions that affect the work, (b) checking progress and quality of work, (c) evaluating the performance of individuals and organizational units, (4) Analyzing trends (trends), and (5) Forecasting external events.

6. Motivating and inspiring (motivating and inspiring), including (a) Using techniques that influence attracting emotions or logic to inspire work, (b) Commitment to task objectives, and (c) Compliance with requests will cooperation, assistance, support or resources, (4) Establish an example of appropriate behavior. 
Tulaihah Ning Safitri, Muhammad Rizqi Hidayat / JURNAL TARBIYAH 26 (2) (2019) 221-236

7. Consultation, including (a) Checking people before making changes that will affect them, (b) Encouraging suggestions for making improvements, (c) Inviting participants in making decisions.

8. Delegating, including: (a) Allowing subordinates to have substantial responsibility and wisdom in carrying out work activities, (b) Dealing with problems, (c) Making important decisions.

9. Providing support, including (a) Acting friendly and caring, patient, and helpful, (b), Showing sympathy and support if someone is confused and anxious, (c) Listening to complaints and problems, (d) looking for someone's interest.

10. Developing and mentoring (developing and mentoring), including (a) Providing training and career advice that helps, (b) Doing things that help the acquisition of one's skills, (c) Professional development, and (d) Career advancement.

11. Managing conflict and team building (managing conflict and team building), including; (a) Facilitating constructive conflict resolution, (b) Encouraging coordination, (c) Teamwork, and (d) Identification with work units.

12. Manage networking, including (a) Socializing informally, (b) Developing contacts with people who are sources of information and support (c) Maintaining contacts through periodic interactions, including visits, telephone, correspondence, and (d) Attendance at meetings and social events.

13. Recognition, including (a) Giving praise and recognition for effective performance, (b) Significant successes and special contributions, (c) Expressing appreciation for one's special contributions and efforts.

14. Giving rewards (rewarding), including (a) Giving or recommending tangible rewards such as additional salary or promotion for effective performance, (b) Significant success, (c) Visible competition.

Next, Ara Hidayat and Imam Machali (2016: 83) added that the Principal as an educational leader must at least have basic managerial competencies, namely as follows: 1. Technical Skills

Skills related to specific knowledge, methods, and techniques in completing tasks. In practice, the involvement of a leader in any form of technical skill is adjusted to the status/level of that leader. 
Tulaihah Ning Safitri, Muhammad Rizqi Hidayat / JURNAL TARBIYAH 26 (2) (2019) 221-236

2. Human Skills

Skills that show a woman's leader in working through others effectively, and to foster cooperation.

3. Cooperation Skills (Conceptual)

This last skill shows the ability to think, such as analyzing a problem, deciding and solving the problem properly. To be able to apply these skills, a leader is required to have a complete understanding (in totality) of his organization. The goal is that he can act in harmony with the overall goals of the organization based on the goals and needs of the group itself.

In the new paragraph of education management, the Principal must at least be able to function as an educator, manager, administrator, supervisor, leader, innovator, and motivator. The future perspective suggests that the Principal must also be able to play a role as a feature and mediator for the development of the community and its environment. All that must be understood by the Principal, and more important is how the Principal can practice and make it in the form of concrete actions at school. The implementation of functions and tasks cannot be separated from each other, because they are interrelated and influence each other, and are integrated with the person of a School Principal (Mulyasa, 2011: 97).

\section{The Performance}

For Veithzal Rivai et al (2008: 14-15) explaining performance refers to the level of success in carrying out the task and the ability to achieve the goals set. Performance or performance is the success of work achieved by a person or group of people in an organization both quantitatively and qualitatively, in accordance with the authority and duties of each responsibility, in an effort to achieve the goals of the organization concerned legally, not violating the law and in accordance with morally and ethics (Moeheriono, 2012: 96-97). According to Tutik Rachmawati \& Daryanto (2013: 16) Affirming that performance is defined as an expression of progress based on knowledge, attitudes, and motivation in producing something work.

From the explanation above about the definition of performance above it can be concluded that the teacher's performance is an effort or tangible evidence of a teacher in carrying out his duties and responsibilities. Efforts to make employees (Teachers) feel at home working for the interests of the organization must be done through psychological 
Tulaihah Ning Safitri, Muhammad Rizqi Hidayat / JURNAL TARBIYAH 26 (2) (2019) 221-236

approaches should pay attention to psychological factors that are generally inherent in employees (Teachers). Teachers' motivation is different from one person to another so that a good work atmosphere development program should be arranged by paying attention to the aspirations and motivations of each according to its category so that goals can be achieved quickly.

Employees (Teachers) will feel at home working in their workplaces if there are facilities available that enable the fulfillment of their needs as humans and not merely as a means of production. The leaders of the organization are very aware of differences in performance between one employee and other employees under different supervision. Although employees work in the same place, their productivity is not the same. Broadly speaking, the difference in performance is caused by two factors, namely individual factors and work situations (Moh As'ad, 1995: 49). Steer (1985: 147) suggests that an individual's performance is strongly influenced by three factors that are interrelated with each other, the three factors are: (1) Factors of ability, temperament, and interest in working. The ability, temperament, and interests of workers are individual characteristics that determine the ability of workers that can affect the performance of an organization. This trait can be considered relatively steady over time, although some changes may occur due to external interactions (such as training). (2) Clarity and recipient factors for the role. Understanding the clarity and acceptance of an individual for the tasks assigned to him increasingly clear when containing the requirements and targets of his work, so that it will be easier to gather energy in the organization to achieve the desired goals. (3) Motivation and performance factors, which are processes that can encourage a worker to improve performance.

Teacher's performance according to Muhibbin Syah (200: 225) is also greatly influenced by the teacher's personality itself and is the most important factor for the success of the task in helping students learn. Syah asserted, that the personality will determine whether he will be a good educator and coach for his students or will be a destroyer or destroyer for the future of his students, especially for students who are still small (elementary level) and those who are experiencing mental turmoil (intermediate level).

Based on the description, that a person's high ability, he will not work professionally if he does not have high work motivation in doing his duties, conversely no matter how high a person's work motivation, he will not work professionally if he does not have high 
Tulaihah Ning Safitri, Muhammad Rizqi Hidayat / JURNAL TARBIYAH 26 (2) (2019) 221-236

ability in doing his duties. To become a professional, he must have work and also high work motivation.

Every individual who is given the task or trust to work in a particular organization is expected to be able to show satisfactory performance and provide maximum contribution to the achievement of organizational goals. Because performance is an indicator of the level of success of a person or group of people in carrying out their duties and responsibilities as well as the ability to achieve goals and standards that have been set. Thus, performance is the result of a particular job function or activity which consists of three aspects, namely: Clarity of tasks or work for which it is responsible; Clarity of expected results from a job or function; clarity of time needed to complete a job so that the expected results can be realized.

\section{Teacher Performance Evaluation (Employee)}

Performance appraisal is the process by which an organization seeks to obtain as accurate information as possible about the performance of members. Here are some uses according to Sondang P. Siagian (2002: 168) of performance appraisal: (1) As a tool to improve employee performance. (2) As an instrument in making adjustments to the benefits provided by the organization to employees. (3) As one source of information for planning and organizing training activities. (4) Studying, whether there are inaccuracies in human resource information systems.

Performance appraisal is used to share goals in the organization. Each organization emphasizes different goals and other organizations can also emphasize different goals with the same assessment system. The diversity of research objectives often illustrates the variation of different objectives regarding performance appraisal. Different goals often lead to conflict. The performance appraisal system will work when the formal goals of the organization use performance that is consistent with the appraisal objectives, including the appraisers and those that are assessed.

\section{RESEARCH METHODOLOGY}

For maximum and objective results in this study used a combination of qualitative research methods and quantitative research. Qualitative research is a research procedure that produces descriptive data in the form of written or oral words from people and observed behavior (Nurul Zuriah, 2006: 92). While quantitative research according to Creswell (2014: 32) as follows, "quantitative research is an approach to testing objective 
Tulaihah Ning Safitri, Muhammad Rizqi Hidayat / JURNAL TARBIYAH 26 (2) (2019) 221-236

theories by examining the relationship between variables. These variables, in turn, can be measured, typically on instruments, so that numbered data can be analyzed using statistical procedures.

Thus he can operationalize that understanding in his research, and this expert's definition can be used as a reason why he uses a quantitative approach in his research. This research is a field research that uses data collection techniques through observation, interviews, and documentation. Next test the validity of the data, according to Moleong (2009: 326-330) data validity checking techniques can be carried out using triangulation techniques. Triangulation means comparing and checking back the degree of trust in the information obtained. After testing the validity of the data, further data analysis is needed through techniques adopted from Miles \& Huberman (1992:20) starting from data collection, then Data Reduction, Presentation of Data, Drawing Conclusions or Verification.

The data sources in this study are the Principal, Daily Task Executors and Teachers of Muhammadiyah Karangturi Elementary School in Yogyakarta. The object of this research is the concept of the Principal's management in improving the performance of elementary school teachers in Muhammadiyah Karangturi Yogyakarta.

\section{Results and Discussion}

Based on data from the field findings, the following is the performance data of teachers on research on the role of school principals in improving the performance of teachers at Muhammadiyah Karangturi elementary school in Yogyakarta, along with supporting and inhibiting factors in improving the performance of teachers at Muhammadiyah Karangturi elementary school in Yogyakarta.

\section{Table 1. Performance Data of Teachers of Muhammadiyah Karangturi Elementary School}

\begin{tabular}{ccc}
\hline Respondents & Total score & Variable Index \\
\hline 1 & 77 & 0,86 \\
\hline 2 & 67 & 0,74 \\
\hline 3 & 77 & 0,86 \\
\hline 4 & 66 & 0,73 \\
\hline
\end{tabular}


Tulaihah Ning Safitri, Muhammad Rizqi Hidayat / JURNAL TARBIYAH 26 (2) (2019) 221-236

\begin{tabular}{ccc}
\hline 5 & 44 & 0,49 \\
\hline 6 & 90 & 1 \\
\hline 7 & 66 & 0,73 \\
\hline 8 & 88 & 0,98 \\
\hline 9 & 88 & 0,98 \\
\hline 10 & 89 & 0,99 \\
\hline
\end{tabular}

Based on Table 1 describes the teacher's task in planning, implementing and evaluating learning. The total score of respondent 1 is 77.00 , and the index variable $\mathrm{x}$ is 0.86 , while the score of respondent 2 is 67.00 , and the index variable $\mathrm{x}$ is 0.74 . Respondent 3 scores 77.00, and index variable $\mathrm{x}$ is 0.86 . Respondents 4 scores amounted to 66.00, and index variable $x$ amounted to 0.73 . Respondents 5 score amounted to 44.00, and index variable x amounted to 0.49. Respondents 6 score totaled 90.0o, variable $\mathrm{x}$ index totaling 1.00. Respondents 7 scores amounted to 66.00, and index variable $\mathrm{x}$ amounted to 0.73 . Respondents 8 total score of 88.00 , and index variable $\mathrm{x}$ amounted to 0.98. Respondents 9 scores amounted to 88.00 , and index variable $\mathrm{x}$ amounted to 0.98 . And Respondents 10 score the number of variables $\mathrm{x}$ is 89.00 and the index variable $\mathrm{x}$ is 0.99 .

Table 2. Analysis of Teacher Performance Category of Muhammadiyah Elementary School Karangturi Yogyakarta

\begin{tabular}{|c|c|c|c|c|c|}
\hline & & Frequency & Percent & Valid Percent & Cumulative Percent \\
\hline \multirow{4}{*}{ Valid } & Not Good & 1 & 10.0 & 10.0 & 10.0 \\
\hline & Good & 3 & 30.0 & 30.0 & 40.0 \\
\hline & Very Good & 6 & 60.0 & 60.0 & 100.0 \\
\hline & Total & 10 & 100.0 & 100.0 & \\
\hline
\end{tabular}

In table 2 you will see the frequency distribution of Teacher performance. The table shows that out of 10 teachers, 1 teacher (10.0\%) was not good. There were 3 teachers (30.0\%) were good, and there were 6 teachers (60.0\%) were very good. After categorizing the performance of elementary school teachers in Muhammadiyah Karangturi into three 
Tulaihah Ning Safitri, Muhammad Rizqi Hidayat / JURNAL TARBIYAH 26 (2) (2019) 221-236

categories, it can be seen that the performance of excellent teachers is greater than teachers who are not good.

From the above table data it can be concluded that the performance improvement of Karangturi Muhamadiyah Elementary School Teachers is GOOD. Seen from the data in the table of 10 elementary school Muhammadiyah Karangturi Teachers that the researchers made a sample of only 1 teacher who was classified as not good.

\section{Teacher Performance Improvement in SD Muhammadiyah Karangturi}

After knowing how the Principal's role strategy towards Teachers, and also based on researchers' observational data on Teachers carrying out learning, the impact that arises then is the result of this strategy which is called the performance of the Elementary School Teacher of Muhammadiyah Karangturi. From the observations and in-depth interviews of the researchers, it is known that the improvement of the teacher's performance is good, and this is evident that namely:

1. The teacher is ready to implement the new curriculum

Previously, Muhammadiyah Karangturi Elementary School only applied one curriculum, the Education Unit Level Curriculum (KTSP). However, in the 20162017 Academic Year, SD Muhammadiyah Karangturi applies two curriculums by adding the 2013 curriculum. Where the 2013 curriculum is in terms of evaluating application-based data input. Nevertheless, the Masters can carry it out according to the provisions.

2. The teacher uses learning strategies that are more creative and innovative.

SD Muhammadiyah Karangturi has a compulsory teaching method used by all teachers in teaching, namely the classical method. However, since implementing the double curriculum, the teachers are more creative by combining the mandatory methods, namely the classical method with technology, by combining the projector in teaching to achieve the learning objectives.

3. The teacher can evaluate student learning by applicable curriculum provisions, namely in cognitive, affective and psychomotor aspects.

4. The teacher teaches not only the material but also moral responsibility.

From the analysis of these data illustrates that the performance of a teacher in addition to personal abilities, the ability of academic qualifications is also a good supporter of performance. To integrate the analysis of the performance of these conditions and needs, it is necessary to answer these actual phenomena based on the state 
Tulaihah Ning Safitri, Muhammad Rizqi Hidayat / JURNAL TARBIYAH 26 (2) (2019) 221-236

of the role of the Principal of the Muhammadiyah Karangturi Elementary School based on factors that emerge in the teacher's performance evaluation.

\section{Conclusion}

Based on the analysis and discussion on "The Role of School Principals in Improving Teacher Performance of Muhammadiyah Karangturi Elementary School in Yogyakarta", the researcher draws the following conclusions:

1. Role of School Principals in improving teacher performance in Muhammadiyah Karangturi Elementary School Yogyakarta. The role of the Principal covers five areas of the Principal's work, namely curriculum management, personnel, student affairs, finance, and facilities and infrastructure. In the five areas of the Principal's work, the Principal delegates his responsibilities by an executor of the Principal's daily duties and is also assisted or involved or fully surrendered to representatives of the management field. However, the Principal does not mean that he does not have a role, in the implementation of the management of the five fields in the field some are indeed the Principals. Besides, in carrying out its management the Principal also functions as the Principal in supervising, monitoring and evaluating the management of the Principal. The strategy adopted or used by the Principal is by one of the competencies that must be possessed by a Principal, namely managerial competence, where the Principal manages the Teachers and staff in the context of optimizing the use of human resources.

2. Improvement of Teacher Performance in Muhammadiyah Karangturi Elementary School Yogyakarta. Teacher performance improvement in Karangturi Muhammadiyah elementary school is good. This is proven that: (a) The teacher is ready to implement two curriculums at once, namely the KTSP curriculum and the 2013 curriculum. (b) The teacher uses learning strategies that are more creative and innovative by the provisions of the 2013 curriculum. (c) The teacher can evaluate student learning by applicable curriculum provisions, namely in cognitive, affective, and psychomotor aspects. (d) The teaching teacher is not only oriented to the material but also a moral responsibility. Besides, the above analysis is supported by observational data that researchers observe the teacher in conducting the teaching and learning process in class. In this case, the researchers used indexing and categorizing data. From the results of data analysis of the performance of elementary school teachers in Muhammadiyah Karangturi, of the 10 teachers 
Tulaihah Ning Safitri, Muhammad Rizqi Hidayat / JURNAL TARBIYAH 26 (2) (2019) 221-236

examined there was 1 teacher whose performance was not good, and the rest had good and very good performance. Therefore, the performance of Karangturi Muhammadiyah Elementary School Teachers can be said to be good. Judging from the many performances of teachers that are categorized as good and very good it can be concluded that the role of the Principal has a positive effect on improving the performance of Teachers of Muhammadiyah Karangturi Elementary School in Yogyakarta.

3. Supporting and inhibiting factors of the Principal's management in improving the performance of Muhammadiyah Karangturi Primary School Teachers.

a. Supporting factors

(1) Strong motivation from school supervisors. (2) Conducive school environment in social interaction, both between teachers, students, and the community. (3) There is positive support from stakeholders both material and non-material, both from parents of students and the community around SD Muhammadiyah Karangturi.

b. Obstacle factor

(1) Very minimal human resources in Karangturi Muhammadiyah Elementary School Teachers. (2) Lack of trust between the supervisor and the Principal. (3) Lack of coordination between fellow activities coordinators.

\section{REFERENCES}

Ahmadi, Abu \& Uhbiyati,Nur. 2007. Ilmu Pendidikan. Jakarta: Rineka Cipta.

As'ad, Mohammad.1995. Psikologi Industri, Yogyakarta: Liberty

Daryanto. 2010. Administrasi Pendidikan, Jakarta: Reneka Cipta

Kadir, Abdul dkk. 2012. Dasar-dasar Pendidikan. Jakarta: Kharisma.

Machali, Imam \& Hidayat, Ara. (2016) The Handbook Of Education Mangement, Teori dan Praktik Pengelolaan Sekolah/Madrasah di Indonesia, Jakarta: Kencana

Mangkunegara, Anwar Prabu. 2004. Manajemen Sumber Daya Manusia Perusahaani. Bandung: Remaja Rosdakarya.

Miles, Mattew B. \& A. Michael Huberman. 1992. Qualitative Data Analysis: A Sourcebook of New Method. Terjemahan Tjetjep Rohendi Rohidi. Analisis Data Kualitatif: Buku Sumber tentang Metode-metode Baru. Jakarta: Penerbit Universitas Indonesia (UI-PRESS). 
Tulaihah Ning Safitri, Muhammad Rizqi Hidayat / JURNAL TARBIYAH 26 (2) (2019) 221-236

Moeheriono.2012. Pengukuran Kinerja Berbasis Kompetensi, Jakarta: Raja Grafindo Persada.

Moleong, Lexi J. 2009. Metodologi Penelitian Kualitatif. Bandung: Remaja Rosdakarya. Mulyasa. 2004. Manejemen Berbasis Sekolah, Bandung: Remaja Rosdakarya Mulyasa.2011. Menjadi Kepala Sekolah Profesional, Bandung: Remaja Rosdakarya Rivai, Veithzal dkk. 2008. Performance Appraisal, Jakarta: PT Raja Grafindo Persada Saroni, Muhammad. 2006. Manajemen Sekolah. Yogyakarta: Ar-Ruzz Media

Siagian, Sondang P. 2002. Kiat Meningkatkan Produktifitas Kerja, Jakarta: Rineka Cipta

Siagian, Sondang P. .2004.Teori Motivasi dan Aplikasinya. Jakarta: Rineka Cipta

Steer, Richard M. 1985. Efektifitas Organisasi, “Terjemahan” Magdalena Jamin, Jakarta: Erlangga

Syah, Muhibbin. 2000. Psikologi Pendidikan dengan Pendekatan Baru, Bandung: Remaja Rosdakarya

Tutik Rachmawati, \& Daryanto. 2013. Penilaian Kinerja Profesi Guru dan Angka Kreditnya, Yogyakarta: Gava Media

Wahjosumidjo. 2007. Kepemimpinan Kepala Sekolah, Tinjauan Teoritik dan Permasalahannya, Jakarta: PT. Raja Grafindo Persada.

Zuriah, Nurul. 2006. Metodologi Penelitian Sosial dan Pendidikan Teori Aplikasi. Jakarta: Bumi Aksara 